\title{
Changes in Postharvest Qualities of Stored Fresh Maize (Zea Mays L.) at Tropical Ambient Condition
}

\author{
I. B. Oluwalana ${ }^{1}$, M. O. Oluwamukomi ${ }^{1}$, A. A. Badejo ${ }^{1}$ and F. A. Bello ${ }^{2}$ \\ ${ }^{11}$ Department of Food Science and Technology, Federal University of Technology Akure, Nigeria) \\ ${ }^{2}$ Department of Food Science and Technology, University of Uyo, Uyo, Nigeria)
}

\begin{abstract}
The effect of passive modified atmosphere packaging on some postharvest qualities of stored fresh maize was investigated at tropical ambient temperature $\left(28 \pm 2{ }^{\circ} \mathrm{C}\right)$ and $80 \% \mathrm{RH}$. Changes in the appearances of husk, silk and kernel, kernel firmness, weight and microbial growth were monitored. Freshly harvested yellow maize (FHYM) served as control. Results showed that packaging film greatly affected the appearances of the husk, silk, kernel and kernel firmness compare to the control sample. The highest weight loss was observed in dehusked maize while the maize samples in packaging film had the least weight loss. Lactobacillus sp., Micrococcus liteus, Streptococcus sp., Serratia marcescens, Bacillus sp. and Saccharomyces cerevisiae were the bacteria isolated from the stored fresh maize while the suspected fungal include Rhizopus stolonifer, Penicillium notatum and Fusarium sp. Higher bacteria counts were observed in samples packaged with 25 and $30 \mu \mathrm{m}$ LDPE while the least was found in unpackaged undehusked maize. The current packaging conditions had no impact on the shelf life of fresh maize.
\end{abstract}

Keywords: Appearances, Fresh maize, Microorganisms, Modified atmosphere packaging, Weight loss

\section{Introduction}

Quality is generally defined as all those characteristics of a food that lead a consumer to be satisfied with the product and it is the main objective of postharvest technology [1]. Assessment of postharvest shelf-life of fresh-cut or minimally processed packaged fruit and vegetables is often based on changes or stability in physical attributes such as colour, firmness and absence of decay. These attributes reflect visual acceptance associated with produce quality. The modified atmosphere packaging technique consists of the enclosure of respiring produce in polymeric films in which the gaseous environment is actively or passively altered to slow respiration, reduce moisture loss and decay and/or extend the shelf life of the products [2]

Maize also known as corn (Zea mays) is a cereal crop which ranks among the most essential crops in the world agricultural economy [3]. It is agronomically versatile and become one of important staple food crops for most part of the population of Africa [4]. Fresh maize kernels are rich source of vitamin C, E, K and Bgroup. Potassium is a major mineral present which has a good significance in human diet [5]. It is a relatively poor cereal when it comes to the quality of its protein, because it has limiting amounts of two essential amino acids, lysine and tryptophan [6]. Although hundred of maize cultivars exist only limited varieties are commercially grown for human consumption and they include dent corn, flint corn, popcorn, waxy corn and sweet maize [7]. Agricultural commodity is a perishable food crop due to the presence of high moisture content [8]. Fresh maize is prone to fast post-harvest deterioration leading to kernel desiccation, loss of sweetness and moisture, husk discoloration and development of pathogens as a result of metabolic reactions [9]. Due to its perishable nature, it has to be consumed immediately after harvest by boiling or roasting. [10] reported that wrapping or sealing a fresh produce with a suitable plastic film reduce moisture loss by creating modified atmosphere around the fruit thereby retarding respiration. The present work was undertaken to test the effectiveness of passive modified atmosphere packaging on the extension of shelf life of fresh maize at tropical ambient temperature.

\section{Materials and Methods}

Ears of fresh yellow maize on the cob (SUWAN 1-SR) was obtained from the Teaching and Research farm of the Federal University of Technology Akure (FUTA). The two different packaging materials used were 25 and $30 \mu \mathrm{m}$ gauges of low density polyethylene (LDPE) with $34 \mathrm{~cm} \times 14.5 \mathrm{~cm}$ in area (TUBI Investment Ltd, Akure, Nigeria). Fresh maize were grouped into six lots: undehusked maize (T1), dehusked maize (T2), undehusked maize packaged with $25 \mu \mathrm{m}$ LDPE (T3), dehusked maize packaged with $25 \mu \mathrm{m}$ LDPE (T4), undehusked maize packaged with $30 \mu \mathrm{m}$ LDPE (T5) and dehusked maize packaged with $30 \mu \mathrm{m}$ LDPE (T6). Freshly harvested yellow maize (FHYM) was harvested daily for comparison purpose and was used as the control sample. The fresh maize was placed singly in LDPE and sealed properly using an impulse sealer (MEC, China). Samples were then transferred into a chamber set at temperature of $28 \pm 2{ }^{\circ} \mathrm{C}$ and $80 \% \mathrm{RH}$ maintained for 8 days. 


\subsection{Physical attributes and weight loss}

Twenty (20) member panelists selected among postgraduate students of FUTA were used to assess the quality of packaged and unpackaged fresh maize under storage. The quantitative descriptive analysis (QDA) method of [11] was used by the panelists where 8-9, 6-7, 4-5, 2-3 and 0-1 represent field fresh, good, fair, non marketable and unusable, respectively. The appearances of kernel, husk, silk and kernel firmness were visually evaluated.Weight losses were determined by measuring the initial and final weight of each packaged and unpackaged maize sample every two days using an electronic weighing balance (ML3002.E, Mettler Toledo, Switzerland). Weight loss was calculated according to the (1):

$\%$ Weight Loss $=\frac{W_{o}-W_{f}}{W_{o}} \times 100$

Where $\mathrm{W}_{\mathrm{o}}$ is the initial weight $(\mathrm{g})$ and $\mathrm{W}_{\mathrm{f}}$ is the final weight $(\mathrm{g})$ prior to package analysis.

\subsection{Microbiological analysis}

\subsubsection{Isolation and cultivation of microorganisms}

The samples were evaluated for microbiological analysis as described by [12]. Packaged and unpackaged stored maize samples were examined for viable count of bacteria and fungi using Nutrient Agar (NA) and Potato Dextrose Agar (PDA), respectively. The pour plate method was used for the enumeration of viable microorganisms. The preparation of each media was carried out according to manufacturer's instructions. Sample was thoroughly homogenized and serially diluted with $0.1 \%$ peptone water up to $10^{4}$. Aliquot of $1 \mathrm{ml}$ portion from the diluents was transferred aseptically into sterile Petri dishes. Melted and cooled NA was added to each plate. The inocula was evenly mixed with media by rotating the plates and allowed to solidify. The inverted plate was incubated at $37{ }^{\circ} \mathrm{C}$ for 1 day and after which the resultant microbial colonies were counted (cfu/g) using a Gallenkamp colony counter. For the enumeration of fungi, aliquot of $1 \mathrm{ml}$ from the diluents was transferred aseptically into solidify PDA plates. Samples were carefully spread all over the surface of the plates using sterile bent glass rod. The plates were then incubated for 5 days at room temperature and the resultant microbial colonies were counted $(\mathrm{cfu} / \mathrm{g})$ using colony counter.

\subsubsection{Biochemical characterization of the isolated bacterial cells}

Gram's staining: Gram's staining technique was carried out using Christian Gram method. A heat-fixed smear from $24 \mathrm{~h}$ old culture was made. A loopful of sterile distilled water was placed on the centre of a clean slide. Aseptically, a very small amount of the culture was transferred into the loopful of water on the slide and emulsified. The slide was allowed to air dry and fixed by passing the slide over flame for 5 times. The smear was stained with crystal violet solution for $1 \mathrm{~min}$ and rinsed with lugol's iodine. The iodine was allowed to react for $1 \mathrm{~min}$. The smear was washed with $95 \%$ alcohol for $30 \mathrm{sec}$ and rinsed gently with water. The smear was counter stained with safranin for $1 \mathrm{~min}$ and washed in water, blot dried and examined under the microscope.

Oxidase: A drop of $1 \%$ aqueous solution of tetramethyl-p-phenylenediamine hydrogen chloride was dropped on a filter paper (No 1 Whatman). The impregnated filter paper was smeared with the bacteria culture with the aid of platinum loop. A purple colouration was produced within $10 \mathrm{~s}$ by oxidase positive culture.

Spore: A heat-fixed smear was prepared. Under steam condition a malachite green solution was added for $10 \mathrm{~min}$. The preparation was carefully washed in cold water. The preparation was counterstained with safranin solution for $15 \mathrm{~s}$, washed with water, blot dried and examined under microscope.

Sugar fermentation: A medium containing $1.0 \%$ peptone, $0.1 \% \mathrm{NaCl}$ and $1.0 \%$ fermentable sugar was prepared. $0.01 \%$ phenol red was added as an indicator including an inverted Durham tube. The medium was sterilized at $121{ }^{\circ} \mathrm{C}$ for $15 \mathrm{~min}$. After sterilization, the tubes were inoculated and incubated $121{ }^{\circ} \mathrm{C}$ for $15 \mathrm{~min}$. Acid production was shown by a change in the colour of the indicator used. Gas production was also indicated by a space in the Durham tube. Sugars tested were glucose, galactose, lactose, sucrose, maltose and manitol.

\subsection{Statistical Analysis}

The statistical significance of the observed differences among the means of triplicates reading of experimental results were evaluated using one way analysis of variance (ANOVA), while means were separated by using Duncan's New Multiple Range Test. These analyses were done with SPSS (20) software.

\section{Results and discussion}

Figure 1 shows changes in physical attributes (husk appearance (A), silk appearance (B), kernel appearance (C) and kernel firmness (D)) of fresh and stored maize under different storage treatments at day 1, 2, 3, 4, 6 and 8. Results showed that the control sample had the highest scores for husk appearance, silk appearance, kernel appearance and kernel firmness while the least was observed in packaged samples. 

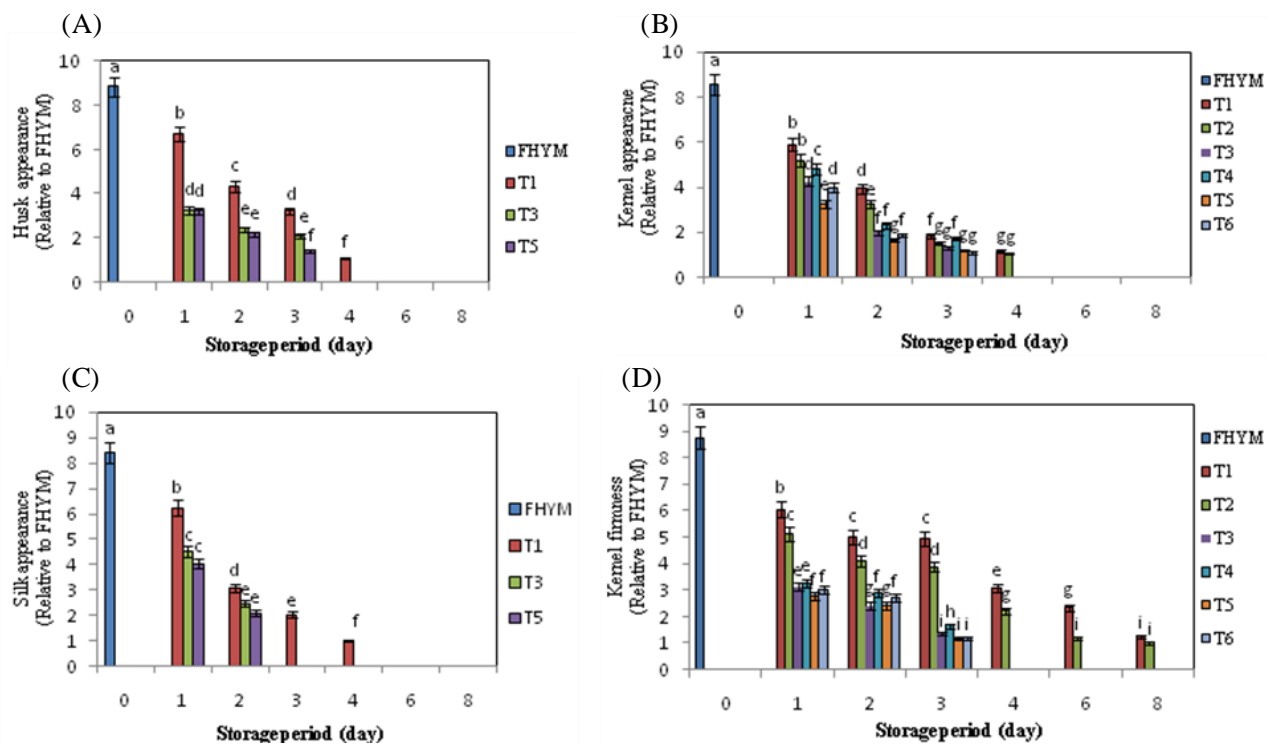

Figure 1: Changes in physical attributes (husk appearance (A), kernel appearance (B), silk appearance (C) and kernel firmness (D) of packaged and unpackaged fresh maize stored at $28 \pm 2{ }^{\circ} \mathrm{C}$. Different letters denote significant differences $(\mathrm{p}<0.05) . \mathrm{T} 1=$ Undehusked maize, $\mathrm{T} 2=$ Dehusked maize, $\mathrm{T} 3=$ Undehusked maize packaged with $25 \mu \mathrm{m}$ LDPE, T4= Dehusked maize packaged with $25 \mu \mathrm{m}$ LDPE, T5= Undehusked maize packaged with $30 \mu \mathrm{m}$ LDPE, T6= Dehusked maize packaged with $30 \mu \mathrm{m}$ LDPE. FHYM (Freshly Harvested Yellow Maize) was harvested daily for comparison purposes. Values are mean $\pm \mathrm{SD}$ of three determinations.

The qualities of the parameter assessed decreased gradually as the storage day progressed. Significant $(\mathrm{p}<0.05)$ differences existed among the treatments. Neither of the film packaging gauges nor the presence of husk preserved the qualities of fresh maize till the last day of storage. At day 3 of storage for T1 (undehusked maize), the husk showed yellowish colour and silk showed brownish colour and both showed dryness. The complete dryness was observed at day 6 and 8 of storage. Undehusked maize samples packaged with $25 \mu \mathrm{m}$ (T3) and with $30 \mu \mathrm{m}$ (T5) were completely water soaked. This could be as a result of the maize respiration which released water as one of the end products. Kernel appearance and kernel firmness followed the same trend of losing its qualities gradually at storage by showing dull kernel appearance with denting for dehusked maize (T2) and to some extent with undehusked maize samples (T1) while packaged samples were water soaked.

Figure 2 shows changes in weight of unpackaged and packaged maize samples. Significant $(p<0.05)$ differences were observed among the treatments. The result showed highest weight loss in T2 (dehusked maize) while the least was observed in packaged samples; undehusked maize packaged with $25 \mu \mathrm{m}$ LDPE (T3), dehusked maize packaged with $25 \mu \mathrm{m}$ LDPE (T4), Undehusked maize packaged with $30 \mu \mathrm{m}$ LDPE (T5) and dehusked maize packaged with $30 \mu \mathrm{m}$ LDPE (T6) followed by T2. The least value observed in packaged samples was indirectly affecting the qualities of the fresh maize.With storage period the amount of water held by a fresh commodity decreases with time so does subsequent water loss and hence weight loss. Water loss in vegetables is determined by many factors, the most important of which is the resistance exerted by the outer periderm or cuticle to movement of water vapour due to transpiration [13]. [14] considered transpiration as the major cause of postharvest losses and poor quality in fresh produce. Weight loss adversely affects the appearance, texture, flavour and all factors that determine the quality of the fruits and vegetables. Weight loss induces wilting, shrinkage and loss of firmness. The observation in this study is in agreement with [15] who reported the highest weight loss for the green mealies stored at room temperature. [16] also reported that there was an interaction that existed between storage condition and weight loss.

The results of microbiological evaluation of unpackaged and packaged maize samples stored at day 2 , 4, 6 and 8 are presented in TABLE 1 . The total aerobic bacterial counts of stored samples at day 2 ranged from $8.17-15.26 \times 10^{4} \mathrm{cfu} / \mathrm{g}$. The use of polymeric films in MAP is intended to serves as a mechanical barrier to the movement of water vapour and reduce produce weight loss as reported by [17] was not effective at ambient temperature. Significant $(\mathrm{p}<0.05)$ increase in bacterial counts was observed in all the treatments as storage days progressed. Packaged samples had the highest microbial counts while least count was recorded for undehusked sample (T1). Proliferation in bacterial counts was observed on day 8 of storage in which all the samples had significantly higher bacterial counts. 


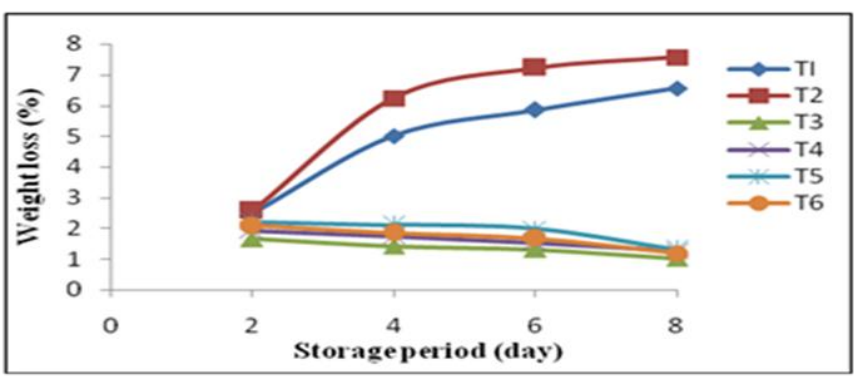

Figure 2: Weight loss of packaged and unpackaged fresh maize stored at $28 \pm 2{ }^{\circ} \mathrm{C}$. $\mathrm{Tl}=$ Undehusked maize, $\mathrm{T} 2=$ Dehusked maize, $\mathrm{T} 3=$ Undehusked maize packaged with $25 \mu \mathrm{m}$ LDPE, T4= Dehusked maize packaged with 25 $\mu \mathrm{m}$ LDPE, T5= Undehusked maize packaged with $30 \mu \mathrm{m}$ LDPE, T6= Dehusked maize packaged with $30 \mu \mathrm{m}$ LDFE. FHYM (Freshly Harvested Yellow Maize) was harvested daily for comparison purposes. Values are means of three determinations.

Table 1: Total aerobic bacteria and fungi $\left(10^{4} \mathrm{cfu} / \mathrm{g}\right)$ of packaged and unpackaged fresh maize at storage temperature $28 \pm 2{ }^{\circ} \mathrm{C}$

\begin{tabular}{|c|c|c|c|c|c|c|c|}
\hline Microbes & SP & \multicolumn{6}{|c|}{ Storage treatments } \\
\hline & (day) & TI & $\mathrm{T} 2$ & T3 & $\mathrm{T} 4$ & T5 & T6 \\
\hline \multirow[t]{4}{*}{ Bacteria } & 2 & $8.53 \pm 0.51^{\mathrm{dA}}$ & $15.26 \pm 1.51^{\mathrm{aA}}$ & $8.17 \pm 1.26^{\mathrm{dA}}$ & $8.41 \pm 1.55^{\mathrm{dA}}$ & $9.01 \pm 1.55^{\mathrm{cA}}$ & $10.67 \pm 1.81^{\mathrm{bA}}$ \\
\hline & 4 & $16.34 \pm 1.22^{\mathrm{eB}}$ & $18.41 \pm 1.87^{\mathrm{dB}}$ & $27.57 \pm 2.54^{\mathrm{cB}}$ & $28.13 \pm 1.87^{\mathrm{bB}}$ & $32.00 \pm 2.41^{\mathrm{aB}}$ & $29.58 \pm 2.35^{\mathrm{bB}}$ \\
\hline & 6 & $17.67 \pm 1.53^{\mathrm{dC}}$ & $24.13 \pm 2.16^{\mathrm{cC}}$ & $32.71 \pm 2.41^{\mathrm{bC}}$ & $30.25 \pm 2.58^{\mathrm{bC}}$ & $40.67 \pm 2.62^{\mathrm{aC}}$ & $33.10 \pm 2.46^{\mathrm{bC}}$ \\
\hline & 8 & $21.71 \pm 2.24^{\mathrm{dD}}$ & $26.88 \pm 2.32^{\mathrm{dD}}$ & $39.22 \pm 2.63^{\mathrm{CD}}$ & $34.10 \pm 1.79^{\mathrm{cD}}$ & $48.11 \pm 2.81^{\mathrm{aD}}$ & $41.10 \pm 2.78^{\mathrm{bD}}$ \\
\hline \multirow[t]{4}{*}{ Fungi } & 2 & $2.32 \pm 0.71^{\mathrm{dA}}$ & $4.21 \pm 1.22^{\mathrm{aA}}$ & $3.87 \pm 1.05^{\mathrm{bA}}$ & $3.15 \pm 0.22^{\mathrm{cA}}$ & $4.26 \pm 0.81^{\mathrm{aA}}$ & $2.46 \pm 0.56^{\mathrm{dA}}$ \\
\hline & 4 & $5.12 \pm 0.48^{\mathrm{dB}}$ & $6.01 \pm 1.05^{\mathrm{cB}}$ & $7.41 \pm 0.85^{\mathrm{aB}}$ & $6.24 \pm 0.65^{\mathrm{bB}}$ & $7.82 \pm 1.42^{\mathrm{aB}}$ & $6.58 \pm 0.85^{\mathrm{bB}}$ \\
\hline & 6 & $9.13 \pm 0.58^{\mathrm{dC}}$ & $11.21 \pm 1.42^{\mathrm{bC}}$ & $14.22 \pm 2.34^{\mathrm{aC}}$ & $9.10 \pm 1.21^{\mathrm{dC}}$ & $11.45 \pm 1.76^{\mathrm{bC}}$ & $10.22 \pm 2.04^{\mathrm{cC}}$ \\
\hline & 8 & $11.81 \pm 1.42^{\mathrm{dD}}$ & $12.76 \pm 1.66^{\mathrm{bD}}$ & $16.11 \pm 2.57^{\mathrm{aD}}$ & $11.22 \pm 1.65^{\mathrm{aD}}$ & $15.33 \pm 2.13^{\mathrm{aD}}$ & $12.11 \pm 1.87^{\mathrm{cD}}$ \\
\hline
\end{tabular}

Different letters denote significant difference $(\mathrm{p}<0.05)$ within each column (capital letters) and row (small letters). SP=Storage period, $\mathrm{T} 1=$ Undehusked maize, $\mathrm{T} 2=$ Dehusked maize, $\mathrm{T} 3=$ Undehusked maize packaged with $25 \mu \mathrm{m}$ gauge LPDE, T4= Dehusked maize packaged with $25 \mu \mathrm{m}$ gauge LDPE, $\mathrm{T} 5=$ Undehusked maize packaged with $30 \mu \mathrm{m}$ gauge LDPE, T6= Dehusked maize package with $30 \mu \mathrm{m}$ gauge LDPE. Values are means $\pm \mathrm{SD}$ of three determinations.

Bacteriological characterization showed six different bacteria (Lactobacillus sp., Micrococcus liteus, Streptococcus sp., Serratia marcescens, Bacillus sp. and Saccharomyces cerevisiae) isolated from the stored samples (TABLE 2).Gradual increase in fungal count was noticed from day 2 to 8 of storage. Three suspected fungal isolated during the course of storage were Rhizopus stolonifer, Penicillium notatum and Fusarium sp. (TABLE 3). Highest count was found in all packaged samples while undehusked samples (T1) had the least count. In all the samples evaluated from day 2 to 8 , it was observed that the counts of fungi (yeasts and moulds) were lowered than the bacteria. This may be attributed to the fact that yeasts and moulds could not thrive well at high $\mathrm{pH}$ (non acidic foods) comparison with aerobic mesophilic bacteria [18, 19].

Table 2: Biochemical characterization of bacterial isolates from stored maize samples

\begin{tabular}{|c|c|c|c|c|c|c|}
\hline & \multicolumn{4}{|c|}{ Number of isolates } & \multirow{2}{*}{5} & \multirow[b]{2}{*}{6} \\
\hline & 1 & 2 & 3 & 4 & & \\
\hline Gram's staining & + & + & + & - & + & + \\
\hline Shape of cells & $\mathrm{R}$ & $\mathrm{S}$ & $\mathrm{S}$ & $\mathrm{R}$ & $\mathrm{R}$ & $\mathrm{S}$ \\
\hline Oxidase & - & - & - & - & - & - \\
\hline Spores & - & - & - & - & + & - \\
\hline Fructose & - & $\mathrm{A}$ & - & $\mathrm{AG}$ & $\mathrm{AG}$ & - \\
\hline Manitol & - & $\mathrm{A}$ & $\mathrm{A}$ & $\mathrm{A}$ & - & - \\
\hline Sucrose & $\mathrm{A}$ & $\mathrm{A}$ & $\mathrm{A}$ & $\mathrm{A}$ & $\mathrm{A}$ & \\
\hline \multicolumn{7}{|c|}{$\begin{array}{l}1=\text { Lactobacillus sp., } 2=\text { Micrococcus luteus, } 3=\text { Streptococcus sp., } 4=\text { Serratia } \\
\text { marcescens, } 5=\text { Bacillus sp., } 6=\text { Sachharomyces cerevisiae, }-=\text { Negative, }+= \\
\text { Positive, } R=\text { Rod, } S=\text { Sphere, } A=\text { Acid, } G=\text { Gas }\end{array}$} \\
\hline
\end{tabular}


Table 3: Cultural characteristics and microscopic observation of the fungal isolates

\begin{tabular}{|l|l|l|}
\hline Cultural characteristics & Microscopic observation & Suspected organisms \\
\hline Cotton-like mycelia at 12 h & Non-septate hyphae, thin sporagiosphore with & Rhizopus stolonifer \\
\hline turning dirty with development & a sporangium in umbrella-like form & \\
\hline of black spores on mycelium & & \\
\hline Blue mould growth & Septate mycelium bearing single conidiophores & Penicillium notatum \\
\hline & which are branched near the apex, ending in & \\
\hline & phialides that carries conidia & \\
\hline The thallus showing pink & Mycelium extensive in a cotton wool-like form. & Fusarium sp. \\
\hline pigmentation fluffy in texture & Having phialides that is bearing a bean podlike & \\
\hline & microconiia borne singly or in chain & \\
\hline
\end{tabular}

\section{Conclusion}

The used of passive modified atmosphere in this study was not effective in keeping the qualities of freshly harvested maize as it was greatly affected the husk appearance, silk appearance, kernel appearance, kernel firmness, increased weight loss and encouraged the proliferation of microorganisms during storage. However, the presence of husk provided a better quality in terms of physical attributes, weight loss reduction and low microbial counts when compared to fresh maize without husk.

\section{References}

[1]. M. Soltani, R. Alimardani, H. Mobli, and S. S. Mohtasebi, Modified atmosphere packaging: A progressive technology for shelf-life extension of fruits and vegetables. Journal of Applied Packaging Research, 7(2), 2015, 33-59.

[2]. S. Mangaraj, T. K. Goswami, and P. V. Mahajan, Applications of plastic films for modified atmosphere packaging of fruits and vegetables: a review, Food Engineering Review, 1, 2009, 133-158.

[3]. H. P. Geetha, V. Palanimuthu and B. Ranganna, A study on shelf-life extension of freshly harvested sweet corn cobs (Zea mays var. Rugosa). Int. J. Proc. and Post Harvest Technol., 5 (2), 2014, 131-135.

[4]. A. Ahmadi1 and P. ziarati, Chemical composition profile of canned and Frozen sweet corn (Zea mays 1.) In iran, Orient. J. Chem., 31(2), 2015, 1065-1070.

[5]. D. Kumar and N. A. Jhariya, Nutritional, medicinal and economical importance of corn: A mini review. Research Journal of Pharmaceutical Sciences, 2, 2013, 7-8.

[6]. R. A. Azevedo, P. Arruda, W. L. Turner and P. J. Lea, The biosynthesis and metabolism of the aspartate derived amino acids in higher plants, Phytochemistry, 46, 1997, 395-419.

[7]. C. D. Boyer and L. C. Hannah, Kernel mutants of corn, In: AR Hallauer (Ed), Specialty corns (CRC Press Inc. Boca Raton, USA, 1994), 1-28.

[8]. S. Mehan, P. Kaur, M. Singh, Studies on Effect of Storage on Quality of Minimally Processed Babycorn, J. Food Process Technol., 5(11), 2014, 388.

[9]. I. B. Oluwalana, Minimizing fruit wastages in Nigeria, International Journal of Agriculture and Food Science, 1(1), 2010, 77-87.

[10]. P. V. Mahajan, O. J. Caleb, Z. Singh, C. B. Watkins and M. Geyer, Postharvest treatments of fresh produce, Philosophical. Transaction of the Royal Society A, 372, 2014, 1-19.

[11]. X. Shao and Y. Li, Quality control of fresh sweet corn in controlled freezing-point storage, African Journal of Biotechnology, 10(65), 2011, 14534-14542.

[12]. W. F. Harrigan, Laboratory methods in Microbiology (Academic Press, Califonia, USA, 1998.

[13]. S. Ben-Yehoshua,, "Transpiration water stress and gas exchange". In: Weichmann, J. (ed), Postharvest Physiology of Vegetables, Marcel Dekker, Inc, New York, NY, 1987, 113-170.

[14]. A. Kader, "Post harvest quality maintenance of fruits and vegetables in developing countries". In: Lieberman, M. (ed) Postharvest Physiology and Crop Preservation, Plenum Press, New York, 1983, 455-470.

[15]. M. T. Masarirambi, S. H. Makhubu, T. E. Sibiya and A. N. Mutukumira, Post-harvest attributes and consumer acceptability of green mealies (Zea mays) stored at ambient and refrigeration temperatures in Swaziland, Agriculture and Biology Journal of North America, (9), 2011, 1261-1269.

[16]. E. Verstreken, J. L. Garcia, M. Ruiz-Altisent and J. De Baerdemaeker, Control Applications in Post- Harvest and Processing Technology (Elsevier Science Ltd, The Boulevard, Langford Lane, Kidlington, Oxford, OX5 1 GB, UK, 1995).

[17]. I. B. Oluwalana, A. O. Ogunsua, S. H. Abiose, and A. F. Eleyinmi, Controlling ripening in mature green plantain (Musa AAB) by irradiation and plastic film packaging, Applied Tropical Agriculture, 10(1), 2005, 54-61.

[18]. Á. Suárez-Jacobo, R. Gervilla, B. Guamis, A. X. Roig-Sagués and J. Saldo, Effect of UHPH on indigenous microbiota of apple juice: a preliminary study of microbial shelf-life, International Journal of Food Microbiology, 136, 2010, 261-267.

[19]. E. Varela-Santos, A. Ochoa-Martinez, G. Tabilo-Munizaga, J. E. Reyes, M. Pérez-Won, V. Briones-Labarca and J. Morales-Castro, Effect of high hydrostatic pressure (HHP) processing on physicochemical properties, bioactive compounds and shelf-life of pomegranate juice, Innovative Food Science and Emerging Technologies, 13, 2012, 13-22. 